Berkala Ilmu Perpustakaan dan Informasi, Vol. 14, No. 2, Desember 2018, Hal. 164-176 DOI: 10.22146/bip.34641

ISSN 1693-7740 (Print), ISSN 2477-0361 (Online)

Tersedia online di https://jurnal.ugm.ac.id/bip

\title{
Ruang produktif dan ruang leisure: bagian dari praktik konsumsi ruang perpustakaan pusat Universitas Gadjah Mada oleh pemustaka digital natives
}

\author{
Endang Fatmawati, Wening Udasmoro dan Ratna Noviani ${ }^{1}$ \\ ${ }^{1}$ Kajian Budaya dan Media, Sekolah Pascasarjana UGM \\ Email: endangfatmawati@undip.ac.id
}

Naskah diterima: 10 April 2018, direvisi: 21 September 2018, disetujui: 22 Oktober 2018

\begin{abstract}
ABSTRAK
Pendahuluan. Praktik konsumsi ruang perpustakaan sangat penting dielaborasi menggunakan perspektif kajian budaya dan media, karena mengelaborasi persoalan mengapa pemustaka digital natives memaknai ruang. Artikel ini merupakan sebagian dari hasil penelitian disertasi, menguraikan praktik sosial dan ruang representasi yang dilakukan oleh pemustaka digital natives di ruang Perpustakaan Pusat UGM.

Metode penelitian. Kualitatif, enam informan dipilih secara purposif. Pengumpulan data menggunakan observasi partisipan, wawancara, dokumentasi.

Data analisis. Pendekatan etnografi yaitu dengan memperhatikan makna tindakan dari kejadian yang terjadi pada pemustaka digital natives.

Hasil dan Pembahasan. Temuan penelitian menunjukkan bahwa ruang Perpustakaan Pusat UGM digunakan dalam dua fungsi yaitu ruang produktif dan non-produktif. Sebagai ruang produktif dan ruang untuk menghabiskan waktu luang berarti ruang Perpustakaan Pusat UGM bagi pemustaka digital natives digunakan untuk belajar atau aktivitas lain yang berhubungan dengan kepentingan kuliah. Sementara itu, ruang nonproduktif mengacu pada ruang untuk menghabiskan waktu luang. Hasil analisis menunjukkan bahwa pemustaka digital natives dalam menghidupkan ruang Perpustakaan Pusat UGM tidak sesuai dengan representasi ruangnya. Ada ketidaksesuaian dengan representasi ruang yang awalnya dirancang dan dikonsepkan oleh pihak Perpustakaan Pusat UGM. Pemustaka digital natives mempunyai cara tersendiri dalam menghidupi ruang Perpustakaan Pusat UGM.

Kesimpulan dan Saran. Ada motif lain dari pemustaka digital natives dalam praktik sosial ketika mengkonsumsi ruang Perpustakaan Pusat UGM. Dari aspek ruang representasi, pemustaka digital natives menghidupinya dengan cara dan dengan kepentingan yang berbeda-beda. Saran penelitian selanjutnya bisa lebih spesifik dalam mengungkap persoalan "mengapa" dari perspektifilmu yang lain.
\end{abstract}

Kata Kunci: Konsumsi ruang, Praktik konsumsi; Waktu luang; Ruang perpustakaan, Pemustaka digital natives

\section{ABSTRACT}

Introduction. The practice of library space consumption is very important to be elaborated by using cultural and media perspective, because it elaborates on the problem of why digital native users interpret of space. This article is part of a dissertation research, which describes social practices and space representation by digital native users at UGMlibrary.

Data Collection Method. It is a qualitative research with participant observation, interviews, and supporting documentation, involving six informants selected purposively.

Analysis Data. Ethnographic approach is carried out by paying attention to the meaning of the actions of the events that occur in digital native users. 
Results \& Discussions. The results showed that UGM library space was used as productive and non-productive space. As productive space means that digital native users leveraged teh space for learning or other activities related to their study. Meanwhile, non-productive space refers to space to spend their leisure activities. The result showed that digital native users in leveraging the space did not correspond to the initial function of the space. There was inconsistency with the representations of space that was originally designed by the UGM library. Digital natives had their own way of leveraging the library space.

Conclusion. There are other motivation how digital native users leveraging the library space. In representational space, digital native users have their own interests. Further research should discuss more specifically in revealing reasons of space use from another theories or perspectives.

Keywords: Consuming space, Consumption practices; Leisure; Library space; Digital native users

\section{A. PENDAHULUAN}

Ruang-ruang yang ada di Perpustakaan Pusat Universitas Gadjah Mada (UGM) selalu mengalami transformasi dan pembenahan. Hal ini misalnya pada bulan Desember 2017 terlihat dari penggabungan ruang terbitan berkala dan ruang referensi, pindahnya ruang sirkulasi ke ruang terbitan berkala, maupun ruangan di depan ruang Electronics Theses Dissertation (ETD) yang awalnya terdiri dari meja komputer kemudian diganti dengan ruang baca dan saat ini menjadi ruang komputer. Kondisi demikian menunjukkan adanya dinamika ruang atau jika meminjam salah satu istilah dari Ranganathan's five laws (1931) dalam Barner (2011) yaitu sebagai "suatu organisme hidup yang terus berkembang". Perubahan era digital juga disertai dengan perubahan tata kelola ruang perpustakaan dan jenis ruangnya. Transformasi yang dilakukan terhadap ruang perpustakaan akan memunculkan praktik konsumsi ruangnya. Asumsi awal bahwa setiap individu pemustaka dalam praktik spasialnya memiliki praktik konsumsi yang berbeda dengan lainnya. Begitu pula khusus bagi pemustaka digital natives, dalam praktik konsumsi ruang pasti memiliki bentuk praktik konsumsi atas ruang Perpustakaan Pusat UGM secara beragam. Hal ini menandakan bahwa adanya praktik konsumsi yang ternyata berbeda dengan konsepsi atas ruang yang dirancang sebelumnya. Padahal konsep sebelumnya dalam representasi ruang, telah memberikan gambaran secara general atas ruang tersebut yaitu untuk kepentingan akademik.

Era digital yang memiliki ciri bahwa akses sumber informasi dapat dilakukan secara real time, namun hal ini justru menjadi "paradoks" karena dalam realitasnya pemustaka juga mengkonsumsi ruang perpustakaan secara fisik. Paradoksnya terletak pada akses informasi yang seharusnya dapat dilakukan tanpa harus datang ke perpustakaan, namun pemustaka justru hadir berkunjung dengan melakukan praktik sosial di ruang perpustakaan.

Pembahasan persoalan konsumsi dapat mencakup banyak aspek, artinya konsumsi bukan hanya konsumsi barang saja, namun dalam konteks penelitian ini yaitu fokus konsumsi ruang perpustakaan. Eksplorasi lebih jauh terkait bagaimana praktik konsumsi ruang perpustakaan dan relasi seperti apa yang kemudian diinginkan, tentu tidak dapat dilepaskan dari sejumlah konteks yang melingkupi pemustaka digital natives dalam menghidupi ruang perpustakaan. Oleh karena penggunaan ruang Perpustakaan Pusat UGM tidak hanya sebagai ruang produktif dalam artian untuk belajar saja, maka perlu dilakukan penelitian ini untuk melihat praktik konsumsi ruang. Berpijak pada latar belakang, maka rumusan masalah dalam kajian ini yaitu "Bagaimana ruang Perpustakaan Pusat UGM dipraktikkan sebagai ruang produktif dan ruang leisure oleh pemustaka digital natives?"

Tujuan penelitian ini untuk mendapatkan gambaran yang komprehensif sekaligus melakukan analisis kritis terhadap praktik konsumsi ruang oleh pemustaka digital natives atas ruang Perpustakaan Pusat UGM. Signifikansi penelitian ini adalah mengelaborasi bagaimana ruang perpustakaan dihidupi oleh pemustaka digital natives dan mengapa mereka memilih ruang Perpustakaan Pusat UGM. Temuan yang terungkap diharapkan dapat mendorong tumbuhnya pengertian bersama 
bahwa ruang perpustakaan pada dasarnya sebagai tempat untuk belajar, namun kenyataan di lapangan bisa melampaui hal itu. Berbeda dengan penelitian-penelitian sebelumnya, kebanyakan penelitian yang sudah dilakukan hanya menekankan aspek teknis ruang perpustakaan, tata ruang perpustakaan, maupun disain interior ruang perpustakaan. Originalitas penelitian ini bukan hanya terletak pada tujuan penelitian yang menggambarkan dan melakukan analisis kritis terhadap praktik konsumsi ruang oleh pemustaka digital natives atas ruang perpustakaan, tetapi juga mengungkap ruang perpustakaan secara praktik sosial dan ruang representasi.

\section{B. TINJAUAN PUSTAKA}

Kajian literatur tentang praktik konsumsi ruang perpustakaan oleh pemustaka digital natives masih terbatas. Namun 2 (dua) penelitian terkait tentang digital natives telah banyak dilakukan. Penelitian sebelumnya terkait digital natives (Gu, Zhu \& Guo, 2013; Helsper \& Enyon, 2009) sedangkan penelitian terdahulu terkait ruang perpustakaan yaitu penelitianUgwuanyi, Okwor \& Ezeji (2011) dan Sequeiros (2013).

Terkait dengan persoalan leisure, kata leisure berasal dari bahasa Latin "licere". Arti licere yaitu diizinkan (to be permited) atau juga bisa menjadi bebas (to be free). Torkildsen (2007) menjelaskan kata lain dari leisure adalah loisir (bahasa Perancis) yang artinya waktu luang (free time). Ilustrasinya "how important the business of leisure and recreation is to society".

Sebagai acuan tentang pemanfaatan ruang perpustakaan oleh pemustaka, maka penjabaran definisi leisure dalam konteks pemustaka digital natives sebagai berikut:

1. Sebagai waktu senggang (leisure as time). Artinya ketika pemustaka digital natives memiliki waktu lebih dan segala kebutuhan yang mudah telah dilakukan, sehingga pada waktu itu mereka dapat melakukan segala sesuatu yang positif sesuai dengan keinginannya;

2. Sebagai aktivitas (leisure as activity). Hal ini terbentuk dari segala kegiatan pemustaka digital natives yang bersifat menghibur. Aktivitasnya berbagai macam kegiatan sehingga biasanya pemustaka digital natives akan mengikuti keinginannya sendiri, misalnya: untuk beristirahat, sekedar menghibur diri sendiri, menambah pengetahuan, maupun mengembangkan keterampilannya secara objektif;

3. Sebagai suasana hati atau mental yang positif (leisure as an end in itself or a state of being). Merupakan sikap pemustaka digital natives yang berhubungan dengan kejiwaan dan keagamaan. Dalam hal ini berarti bukan merupakan hasil dari waktu senggang, liburan, akhir pekan, liburan panjang, maupun bukan disebabkan oleh faktor yang berasal dari luar;

4. Sebagai sesuatu yang memiliki arti luas (leisure as an all embracing). Artinya merupakan ekspresi dari seluruh aspirasi pemustaka digital natives dalam upaya mencari kebahagiaan, baik itu terkait dengan kegiatan relaksasi, hiburan, maupun pengembangan diri;

5. Sebagai suatu cara untuk hidup (leisure as a way of living). Artinya suatu kehidupan pemustaka digital natives yang dirasakan dapat bebas dari tekanan yang berasal dari luar budaya pemustaka digital natives dan lingkungannya. Dalam tataran ini mereka mampu untuk bertindak sesuai kepentingannya, sehingga yang penting adalah apa yang dilakukan itu dapat menyenangkan mereka.

Hasil penelitian Choy \& Goh (2016) menunjukkan bahwa perpustakaan perguruan tinggi yang baik harus menyediakan berbagai macam ruang. Hal ini penting untuk menyediakan dan menyeimbangkan sesuai kebutuhan mahasiswa. Selanjutnya Oliveira (2018) menjelaskan bahwa manajemen puncak di perpustakaan perguruan tinggi memainkan peran yang sangat penting dalam hal pengaturan ruang yang mampu menyelaraskan dengan gaya preferensi belajar pemustaka saat ini.

Mencermati penelitian sebelumnya, tampak ada celah penelitian yang dapat dilakukan sehingga memiliki perbedaan spesifik dari penelitian sebelumnya. Posisi penelitian ini 
berfokus untuk mengeksplorasi dari perspektif kajian budaya dan media terkait praktik konsumsi terhadap ruang perpustakaan dengan menggunakan konsep praktik sosial dan ruang representasi. Selanjutnya terkait penggunaan istilah "spasial" dan "sosial", dalam Wilson (2013: 367) dikatakan bahwa Lefebvre tidak membedakan praktik sosial dengan praktik spasial, sehingga "praktik spasial adalah praktik sosial". Dari hasil pengamatan, terutama prodi Ilmu Perpustakaan di Indonesia, bahwa selama ini kecenderungan penelitian tentang perpustakaan bersifat positivistik kuantitatif dan belum mengeksplorasi persoalan why.

Dalam tataran ini, praktik konsumsi pemustaka digital natives atas ruang perpustakaan dari sisi cultural studies belum cukup terungkap. Hubungan kajian budaya yang berhubungan dengan penelitian ini adalah menyoroti pada aspek kritis.

\section{METODE PENELITIAN}

Metode penelitian menurutFaruk (2014: 58) merupakan teknik untuk memperoleh pengetahuan mengenai objek tertentu yang kodrat keberadaannya dinyatakan oleh teori. Dalam penelitian ini, objek yang dimaksud adalah ruang perpustakaan, sedangkan teorinya menggunakan konsep praktik sosial dan ruang representasi (Henri Lefebvre, 1991) sebagaimana dikutip Schmid (2008), konsep waktu luang (Thorstein Veblen, 2007) dan konsep teori lainnya untuk menegaskan atau menggarisbawahi dalam menganalisis data. Fokus utama penelitian ini berkenaan dengan bagaimana praktik konsumsi ruang perpustakaan oleh pemustaka digital natives. Dalam metodologi penelitian ini dispesifikasikan dengan menggunakan metode kualitatif dengan pendekatan etnografi. Pendekatan etnografi dilakukan dengan memperhatikan makna tindakan dari kejadian yang terjadi pada pemustaka digital natives, yang terekspresikan secara langsung dalam bahasa, kemudian diterima maupun disampaikan secara tidak langsung melalui kata dan perbuatan. Connaway \& Radford (2017: 197) menyebutkan bahwa "Ethnography involves establishing rapport, selecting research participants, transcribing observations and conversations, and keeping diaries...". Selanjutnya Blasco \& Wardle (2007: 5) menambahkan bahwa etnografer juga harus mampu "comparison, contextualization of life world, and exposition of the relationships involved...".

Informan dipilih secara purposive yang tergolong pemustaka digital natives dengan kriteria: selalu datang memanfaatkan ruang Perpustakaan Pusat UGM, sering berkunjung di ruang perpustakaan, selalu menggunakan gawai di ruang perpustakaan, tingkat keterpaparan terhadap teknologi digital tinggi, dan banyaknya frekuensi penggunaan internet dalam kehidupan mereka. Keenam informan yang dipilih cukup menghasilkan banyak variasi pandangan atas keberagaman (polyvocality) dan merepresentasikan pemustaka digital natives. Cara pengumpulan data yang dianggap relevan dengan permasalahannya, yaitu observasi partisipatif, wawancara, dan dokumentasi. Ketiga teknik tersebut digunakan secara bersamaan untuk saling melengkapi satu sama lain. Oleh karena kualitatif maka alat pengumpul datanya adalah orang yang melakukan penelitian. Penelitian dilakukan melalui observasi deskriptif terlebih dahulu atas aktivitas informan untuk mendapatkan informasi sebanyak mungkin. Analisis dilakukan secara dialektik dan tidak linear untuk mengetahui berbagai hal yang perlu ditelusuri lebih jauh, dilengkapi, ataupun ditanyakan ulang dengan segera kepada para informan. Analisis data di mulai dengan mengumpulkan data, mencoba menalar dan menganalisis, lalu kembali melihat interpretasinya sudah masuk atau belum untuk menjelaskan pengalaman baru, mengumpulkan lebih banyak data lagi, kemudian memilah interpretasi untuk dianalisis secara lebih mendalam.

\section{HASILDAN PEMBAHASAN}

Beberapa temuan menarik hasil penelitian terkait praktik konsumsi ruang Perpustakaan Pusat UGM. Agar bahasan lebih fokus, dalam artikel ini hanya dijelaskan yang terkait dengan ruang Perpustakaan Pusat UGM sebagai ruang produktif dan ruang leisure. Jika dicermati, 
pemustaka digital natives yang menggunakan ruang kelas diasumsikan mereka sedang kuliah, sehingga kondisi yang demikian merujuk pada aktivitas pemustaka digital natives selama waktu produktifnya. Hal ini berangkat dari kerangka status pekerjaan atau profesi mereka sebagai mahasiswa, berarti waktu produktif merujuk pada masa di mana pemustaka digital natives mengikuti kegiatan belajar-mengajar dalam sebuah ruang kelas, mengerjakan tugas yang mendukung perkuliahannya, maupun sedang belajar baik individu maupun secara kelompok. Semua fasilitas, aspek materialitas elemen lainnya, dan aparatus yang tersedia di ruang Perpustakaan Pusat UGM dimanfaatkan untuk menambah pengetahuan dan pengayaan mata kuliah yang diperolehnya di perkuliahan.

Temuan penelitian ternyata ruang produktif selain untuk belajar (secara representasi ruang adalah produksi "ide"), juga dipraktikkan sebagai ruang untuk menghasilkan uang bagi mereka (producing money). Ruang virtual yakni ruang yang digunakan pemustaka digital natives melakukan business online dengan memanfaatkan fasilitas internet. Informan rajin meminjam buku-buku di ruang sirkulasi sebagai bahan untuk memperkaya literatur dalam rangka mendukung online bisnisnya menulis di blog. Ia memanfaatkan betul bahwa mahasiswa bisa meminjam buku 10 eksemplar selama 20 hari, bahkan ia selalu rutin meminjam karena termotivasi untuk bahan mencari inspirasi aktivitas menulisnya. Oleh karena untuk mengisi waktu luang, ia juga selektif memilih bacaan yang sifatnya "ringan" sekalipun berhubungan dengan teknologi informasi yang ia sukai. Baginya ada keuntungan ganda, dapat memanfaatkan waktu luangnya dengan membaca buku, kemudian di sisi lain output membacanya dapat menghasilkan tulisan kembali yang ia tulis di blog. Dengan demikian, leisure di ruang perpustakaan ia peroleh sedangkan producing money juga diraihnya.

Ada juga yang memaknai sebagai basis riset untuk mendukung bisnisnya dalam berjualan tanaman karnivora secara online melalui media sosial. Ruangan yang nyaman menjadi alasan mengapa mereka memilih ruang Perpustakaan Pusat UGM sebagai tempat fisik (library as place) untuk menjalankan bisnis mereka secara virtual. Temuan penelitian diabstraksikan sebagai ruang producing money karena ruang Perpustakaan Pusat UGM ternyata juga dijadikan sebagai ruang untuk online shopping. Ruang Perpustakaan Pusat UGM ternyata dijadikan "arena" untuk menjalankan business online yang digeluti informan. Ruang Perpustakaan Pusat UGM bagi pemustaka digital natives berarti sangat menyenangkan untuk berselancar ke internet (connecting pleasure).

Rangkaian temuan penelitian sebelumnya, Fatmawati (2017c) semakin kuat bahwa sekalipun era online, namun kenyataannya ruang-ruang yang ada di Perpustakaan Pusat UGM secara fisik selalu ramai dikunjungi pemustaka digital natives, bahkan "ruang" di area selasar yang menghubungkan antar ruang juga selalu dikonsumsinya. Hal inilah yang melatarbelakangi dan memantik kecurigaan untuk melakukan penelitian lanjutan. Hasil observasi awal bahwa pemustaka digital natives sangat akrab menggunakan gawai dan selalu connected. Penelitian selanjutnya bahwa pemustaka digital natives ternyata telah melakukan alih fungsi Perpustakaan Pusat UGM sebagai tempat ketiga, mereka mengkonsumsinya menjadi ruang alternatif selain di kost dan rumah(Fatmawati, 2017a).

Hasil wawancara dengan mahasiswa yang bekerja paruh waktu di Perpustakaan Pusat UGM diperoleh informasi bahwa ruang Perpustakaan Pusat UGM sebagai tempat di kampus yang paling kondusif, karena bisa belajar, bekerja, maupun menggunakan wifi gratis. Saat ia bekerja paruh waktu, berarti mengasah kemampuan soft skill juga, yaitu bagaimana melayani, berkomunikasi, bergaul, dan bekerja dalam sebuah tim. Selanjutnya pada saat tidak sedang shift kerja, maka bisa beralih peran sebagaimana mahasiswa yang berkunjung dan mengkonsumsi ruang-ruang yang disediakan di Perpustakaan Pusat UGM. Pada saat pemustaka digital natives menggunakan waktu luangnya di ruang Perpustakaan Pusat UGM, berarti menyoroti aktivitas dalam kategori "nonproduktif atau tidak produktif".

Dalam konteks praktik sosial, temuan 
penelitian memperlihatkan bahwa pemustaka digital natives juga mengkonsumsi ruang Perpustakaan Pusat UGM untuk menghabiskan waktu luang (leisure). Hal ini nampak ketika mereka selalu menghabiskan waktu dengan berada di ruang Perpustakaan Pusat UGM, seperti: di sela-sela menunggu jam kuliah berikutnya, hari Sabtu Minggu, kemudian mereka baru keluar ruang perpustakaan setelah jam kunjung usai di malam hari. Apalagi di abad 21 peran perpustakaan dituntut sebagai sumber ilmu pengetahuan dan menghasilkan pengetahuan baru. Perpustakaan dalam pandangan Lee (sebagaimana dikutip oleh Fagbola, Uzoigwe, Ajegbomogun, 2011) bahwa perpustakaan "to be learning and knowledge center for their users as well as the intellectual commons for their respective communities where". Selanjutnya jika meminjam istilah dari "Keystone Principles" bahwa "people and ideas interact in both the real and virtual environments to expand learning and facilitate the creation of new knowledge".

Terkait dengan temuan penelitian ruang perpustakaan sebagai ruang leisure, waktu luang (free time) di Perpustakaan Pusat UGM menjadi ruang rekreasi bagi pemustaka digital natives untuk memenuhi kesenangan (pleasure). Informan menganggap bahwa tidak ada aturan yang ketat saat berkunjung ke ruang diskusi, ruang belajar mandiri, dan ruang karya ilmiah. Mereka bisa membawa tas dan barang bawaannya masuk ke dalam ruangan, membawa makanan dan minuman, serta membawa seperangkat gawai yang mendukung aktivitasnya.

Kondisi ruang perpustakaan yang secara representasi ruang diatur dengan sistem terbuka, semakin membuka peluang lebar bagi pemustaka digital natives untuk melakukan praktik sosialnya ketika berada di dalam ruang perpustakaan. Dalam tataran ini, ada komponen lainnya seperti psikologik dan sosial yang turut berpengaruh pada diri pemustaka digital natives. Ruang tidak hanya bergantung dari kondisi fisik saja namun juga dipengaruhi oleh komponen psikologik dan komponen sosial. Kondisi fisik yaitu pengaturan dari ruang perpustakaan (bagaimana bentuk ruang, luas ruang, dan hal lain yang dapat dirasakan). Komponen psikologik yaitu interaksi yang terjadi di dalam ruang perpustakaan, sedangkan komponen sosial yaitu hubungan yang terjadi di dalam ruang perpustakaan.

Jika didialogkan dengan konsep dari Lefebvre (pemikir Marxis) bahwa perspektif ruang sosial itu sebagai hasil dari serangkaian relasi sosial. Ruang Perpustakaan Pusat UGM dikonsumsi sedemikian rupa oleh pemustaka digital natives dengan melalui hubungan yang bersifat sosio-historis. Ruang yang ada di Perpustakaan Pusat UGM yang tidak prosedural sangat cocok untuk mengakomodir kebutuhan mereka. Informan senang mengunjungi ruang Perpustakaan Pusat UGM terlebih ketika menunggu waktu untuk masuk kuliah jam berikutnya, di samping memang ia memiliki hobi suka sekali membaca, sehingga label "kutu buku" baginya sangat tepat jika mereka sering bergelut dengan bahan bacaan.

Ada informan yang senang ke Perpustakaan Pusat UGM karena motifnya sekedar santai menunggu waktu untuk berpindah ke waktu produktifnya yaitu kuliah, hanya sekedar membaca buku-buku yang ringan, menonton youtube, menonton film, mengecek email, chatting melalui media sosial, maupun bisa leluasa bermain game online. Kondisi yang mendukung kepentingan ini karena ada fasilitas wifi, di samping juga kondisi ruang Perpustakaan Pusat UGM yang menurutnya sangat nyaman untuk bisa bersantai menghabiskan waktu luang. Bahkan hari yang tidak ada kuliah sekali pun, ia selalu ke kampus dengan sasaran ke ruang Perpustakaan Pusat UGM yang menyediakan sofa sehingga ia bisa tiduran sambil membaca. Adanya tata tertib, informan merasa berada di rumah atau di kost, karena tetap bisa memakai memakai sandal dan membawa bekal kebutuhan primer (makan minum) ke dalam ruang Perpustakaan Pusat UGM.

Mencermati alasan yang dikemukakan oleh pemustaka digital natives, diketahui bahwa mereka berkunjung dan berada di ruang Perpustakaan Pusat UGM lebih karena memang muncul hasrat dari hati. Ruang Perpustakaan Pusat UGM menjadi favorit pilihan ruang untuk 
menghabiskan waktu luang dibanding dengan ruang lainnya di lingkungan kampus. Aktivitas nongkrong bagi mereka di ruang Perpustakaan Pusat UGM. Pada titik ini, mengindikasikan bahwa transformasi ruang yang intens dilakukan oleh pihak manajemen Perpustakaan Pusat UGM dapat mengakomodir kebutuhan pemustaka digital natives. Artinya bahwa jika pemustaka digital natives tidak ke ruang Perpustakaan Pusat UGM, maka tidak akan mendapatkan fasilitas kenyamanan dari sebuah ruang.

Dengan demikian, pada kondisi ini ada kepentingan yang muncul dari pemustaka digital natives di dalam konteks praktik konsumsi ruang perpustakaan tersebut. Fakta empiris dari hasil penelitian menunjukkan adanya praktik sosial lainnya. Hal ini jika dianalisis dengan konsep triadic Lefebvre, maka dari kedua aspek ("praktik sosial" dan "ruang representasi") berarti realitasnya tidak sesuai dengan aspek "representasi ruang" yang sebelumnya diset atau dirancang oleh konseptor ruang. Artinya bahwa ada perilaku pemustaka digital natives di ruang Perpustakaan Pusat UGM yang "di luar" untuk memenuhi kebutuhan terkait perkuliahan dan kepentingan akademik. Pengakuan informan yakni bisa melihat dan mengakses banyak hal ketika berada di ruang Perpustakaan Pusat UGM. Padahal secara konsep dalam representasi ruang, ruang perpustakaan tidaklah didesain seperti itu. Adanya kepentingan lain yang turut mengatur hadirnya beragam jenis ruang di Perpustakaan Pusat UGM termasuk munculnya corner-corner tiada lain untuk kepentingan akademik. Hal ini seperti pendapat Fatmawati (2017b) mengenai "representasi ruang perpustakaan", bahwa ruang Perpustakaan Pusat UGM tidak hadir dengan sendirinya, namun juga diatur dan dikembangkan dengan kontestasi beragam kepentingan eksternal.

Seperti halnya temuan penelitian ini, misalnya pemustaka digital natives saat di ruang Perpustakaan Pusat UGM justru karena persoalan leisure. Schmid (2008: 37) mengungkapkan bahwa para perancang ruang ketika berbicara tentang representasi ruang maka ada level wacana, yang secara jelas dapat memberikan gambaran dan definisi atas ruang yang ada. Dalam konteks ini, dapat disimpulkan bahwa pemustaka digital natives berada di ruang Perpustakaan Pusat UGM karena memiliki motif memang sengaja untuk mengkonsumsi ruangnya (consuming space). Istilah "konsumsi" (consumption) berasal dari bahasa Latin "consumare" yang artinya untuk mewujudkan. Konsumsi berarti membawa ke pemenuhan, karena dalam praktik sosial pemustaka digital natives tidak menyukai berada di kamar saja, apalagi jika berada di kostkostan seringnya merasa bosan, cepat mengantuk, terasa panas, dan sering terganggu oleh teman kost. Ibaratnya jika di kost hanya terbatas pandangannya dalam lingkup spasial terbatas dan banyak tekanan sosial, sedangkan kalau berada di ruang Perpustakaan Pusat UGM maka bisa lebih luas jangkauan aktivitasnya. Pemaknaan mereka serasa "feel at home", karena semua informan mengamini bahwa selain bisa serius, namun juga bisa santai, tiduran, makan minum, ngadem, mengobrol, berselancar ke internet, dan lain sebagainya.

Ruang Perpustakaan Pusat UGM juga sebagai ruang katarsis untuk melarikan diri dari tekanan lingkungan mereka. Pemustaka digital natives mencari kebebasan di ruang Perpustakaan Pusat UGM. Dari hasil kajian mendalam ternyata ruang perpustakaan tidak seperti image yang sebelumnya berkembang atau dominan selama ini. Stereotip perpustakaan "birokratis dan penuh aturan" ternyata tidak ditemukan oleh pemustaka digital natives, sehingga ketika menghidupi ruang mereka mengambil peluang dan memanfaatkan betul ruang yang ada dengan beragam fasilitasnya. Ruang yang variasinya banyak lebih dari 10 ruang sangat memungkinkan bagi mereka untuk memilih. Dalam praktik sosialnya, pemustaka digital natives juga memiliki agency tersendiri dalam mengkonsumsi ruang-ruang tersebut.

Oleh karena konsep waktu luang menurut Veblen mengarah pada konsumsi waktu yang sifatnya "nonproduktif atau di luar kerja", maka dalam konteks penelitian ini berarti pendekatan relasional dengan kerja menjadi pendekatan klasik dalam melihat waktu luang sebagai sebuah konsep. Kelas dalam perspektif Veblen 
(2007) merupakan suatu kelas yang berorientasi pada "penghindaran" segala sesuatu yang berhubungan dengan pekerjaan produktif, sehingga konsep kelas dalam arti bentuk konsumsi tersebut menjadi bagian penting dari kelas ekonomi Veblen. Hal ini senada dengan Pieper dalam buku Leisure: The Basis of Culture yang juga menjelaskan keterkaitan antara waktu luang dengan kerja, bahwa ketika berada di waktu senggang adalah untuk bersenangsenang, "we are not-at-leisure in order to be-atleasure".

Leisure class menurut Veblen merupakan kelas yang unik karena berkaitan dengan aktivitas pola konsumsi waktu luang yang dilakukan dan dinikmati oleh sekelompok kelas tertentu sebagai gaya hidup. Terminologi gaya hidup akan terkait dengan terminologi konsumsi. Konsumsi (consumption) atau "the act of consuming" artinya tindakan untuk mengkonsumsi, yaitu: memanfaatkan, menggunakan, atau menikmati sesuatu yang bersifat material atau nonmaterial. Cirinya yaitu conspicuous leisure dan conspicuous consumption, yang artinya pola pengkonsumsian barang dan waktu luang yang berlebihan.

Dalam konteks penelitian ini, pemustaka digital natives ketika berada di ruang Perpustakaan Pusat UGM menjadikan ibarat sebagai kehidupan yang serba menyenangkan (life of leisure). Pemustaka digital natives menggunakan ruang perpustakaan untuk life style yaitu sebagai ruang untuk menunjukkan siapa mereka (yang mempunyai banyak hal). Ruang perpustakaan itu ternyata menjadi ruang display untuk membangun distingsi identitas dan gaya hidupnya. Apalagi pada era normal baru, pemustaka digital natives membangun distingsi dengan pemustaka lainnya melalui perilaku yang berbeda (Fatmawati, 2018). Hal ini misalnya: ativitas mencari informasi, aktivitas memilih ruang, mengkonsumsi gawai, menggunakan vending machine kartu elektronik (e-money mandiri, kartu BRIZZI, KTM berlogo BRIZZI) untuk membeli minuman, dan lain sebagainya. Dalam konteks life style, ketika masuk dan berada di dalam ruang perpustakaan, para pemustaka digital natives cenderung men- display kapital-kapital yang dipunyainya. Ruang perpustakaan menjadi ruang dimana mereka bisa dilihat oleh pemustaka lain. Mereka sama-sama menggunakan gawai, sehingga menunjukkan distingsi tersendiri dengan pemustaka lainnya yang tidak tergolong digital natives.

Waktu luang berfungsi sebagai pemenuhan kebutuhan sosial bagi pemustaka digital natives, sehingga mampu memicu perkembangan psikomotorik, kognitif, sosial, dan emosional. Dalam tataran ini, waktu luang bagi pemustaka digital natives saat berada di ruang Perpustakaan Pusat UGM berarti "bukan merupakan waktu produktif". Waktu luang yang dimaksud dalam penelitian ini adalah menjadi waktu bebas bagi pemustaka digital natives, sehingga tidak digunakan untuk kegiatan rutin belajar sebagai mahasiswa. Artinya pada saat di ruang Perpustakaan Pusat UGM bukan merupakan working time bagi pemustaka digital natives tersebut. Dari hasil wawancara diketahui bahwa pemustaka digital natives sangat menikmati berada di ruang perpustakaan, sangat senang berlama-lama dalam ruangan bahkan sampai Perpustakaan Pusat UGM menjelang tutup layanan.

Faktor yang mendorong atau memotivasi pemustaka digital natives mengkonsumsi ruang Perpustakaan Pusat UGM adalah karena tujuan kesenangan (leisure destinations). Secara lebih nyata tindakan mengkonsumsi ruang Perpustakaan Pusat UGM yang dilakukan oleh pemustaka digital natives merupakan sebuah pernyataan untuk memposisikan diri mereka dalam praktik sosial di ruang perpustakaan. Oleh karena ruang yang dihasilkan juga berfungsi sebagai "alat pemikiran dan tindakan", maka secara ruang representasinya dapat dikatakan bahwa konsumsi ruang menjadi suatu tindakan yang dihidupkan oleh pemustaka digital natives melalui praktik sosial selama berada di ruang Perpustakaan Pusat UGM.

Praktik sosial sebagai sebuah praktik atau aktivitas yang dilakukan pemustaka digital natives terhadap tempat fisik (ruang Perpustakaan Pusat UGM) di mana aktivitas yang dilakukannya akan berpengaruh dalam proses pemaknaan ruang secara lebih spesifik. 
Praktik sosial terdiri dari produksi dan reproduksi ruang. Secara sederhana dapat dijelaskan sebagai sebuah bentuk pemaknaan pemustaka digital natives terhadap ruang Perpustakaan Pusat UGM. Suatu contoh, seorang pemustaka digital natives menggunakan ruang perpustakaan untuk melakukan bisnis. Berarti dapat dikatakan bahwa ia sedang memaknai sebuah ruang untuk melakukan bisnis online karena adanya fasilitas wifi. Jadi ruang Perpustakaan Pusat UGM dalam konteks ini menjadi tempatnya melakukan kegiatan produksi. Lalu sebuah pemfungsian dan pemaknaan menjadi lebih spesifik pada saat mereka memaknainya sebagai tempat yang dalam konteks ini disebut sebagai "ruang untuk menghabiskan waktu luang".

Berkunjung ke ruang perpustakaan menjadi kebutuhan pemustaka digital natives. Sebagai ruang yang dilengkapi dengan berbagai fasilitas pendukung, diketahui adanya motivasi yang mendasari pemustaka digital natives menghabiskan waktu luang di ruang Perpustakaan Pusat UGM. Aktivitas leisure lainnya seperti halnya mengakses youtube, menonton film, serta dalam waktu yang bersamaan juga produktif make money seperti mengembangkan bisnisnya. Kondisi ini didukung dengan kondisi ruang Perpustakaan Pusat UGM yang nyaman sehingga bisa sebagai stimulus menyegarkan pikiran mereka. Pada titik ini aktivitas lain yang dilakukan dalam rangka menghidupi ruang perpustakaan, memberikan semangat baru dalam mendukung kegiatan utamanya sebagai mahasiswa. Artinya bahwa kegiatan pemustaka digital natives yang menghabiskan waktu luangnya di ruang Perpustakaan Pusat UGM sebagai suatu aktivitas yang menyenangkan di luar kegiatan rutin untuk belajar. Hal ini dibuktikan dari praktik sosial yang dilakukan oleh pemustaka digital natives yang menggunakan ruang-ruang tersebut sesuai kepentingannya di luar mengerjakan tugas kuliah.

Dahulu tidak ada yang namanya praktik sosial ruang perpustakaan yang di luar selain sebagai ruang belajar. Namun dengan lahirnya generasi pemustaka digital natives, maka membuat praktik sosial yang saat ini ada menjadi bergeser, begitu juga aktivitas mereka dalam menghidupi ruang perpustakaan. Kondisi tersebut hadir karena dalam konteks ini muncul hal lain bahwa selain pemustaka digital natives belajar, dengan adanya fasilitas wifi ternyata sangat memungkinkan bagi mereka untuk menghidupi ruangan dengan selalu online untuk mengikuti "semua perkembangan global". Artinya ketersediaan akses internet gratis dimanfaatkan betul oleh pemustaka digital natives. Baudrillard (2009) mengatakan bahwa di dunia cyberspace menyebabkan tindakan dan aktivitas berinternet yang dilakukan pengguna adalah memiliki nilai tukar. Semua aktivitas di dunia internet dapat dipertukarkan dan memiliki nilai strategis untuk dikapitalkan.

Pemustaka digital natives menjadi diuntungkan saat menggunakan ruang Perpustakaan Pusat UGM, karena kondisi ruangan yang nyaman dan didukung dengan beragam fasilitas yang mengakomodir kepentingan mereka. Tersedianya fasilitas wifi di semua ruang Perpustakaan Pusat UGM sangat mempermudah pemustaka digital natives untuk selalu connected. Perilaku menggeser kursi, menaruh barang-barang di meja kursi untuk booking tempat, membawa berbagai perangkat digital (laptop, smartphone, earphone, powerbank, dan lain sebagainya) menjadi pemandangan sehari-hari di ruang Perpustakaan Pusat UGM.

Ruang-ruang yang ada di Perpustakaan Pusat UGM sebagai ruang sosial yang tentu tidak bisa dilepas dan selalu dikaitkan dengan realitas sosial yang mengelilinginya. Dari hasil pengamatan sering dijumpai adanya barangbarang di meja kursi tergeletak begitu saja seperti tidak bertuan, namun sebetulnya ada yang memiliki, karena mereka sedang di luar ruangan tersebut. Mereka sengaja melakukan "booking" tempat dan merasa tenang walaupun meninggalkan barang-barangnya di ruangan. Faktor keamanan juga relatif bisa dirasakan oleh pemustaka digital natives, sehingga kondisi ini menjadi salah satu alasan logis ruang Perpustakaan Pusat UGM selalu didatangi oleh pemustaka digital natives. Fakta empiris lainnya bahwa sering terdengar announcer dari petugas di bagian informasi yang sering mengumumkan 
jika ada barang yang tertinggal di lingkungan Perpustakaan Pusat UGM. Bahkan jika lama tidak diambil di Perpustakaan Pusat UGM juga ada tempat display tersendiri khusus barang yang tertinggal di perpustakaan.

Karakter yang menyertai praktik spasial adalah perceived space, artinya ruang Perpustakaan Pusat UGM memiliki aspek perseptif yang dapat ditangkap oleh panca indera pemustaka digital natives. Praktik sosial menjadi sebuah praktik atau aktivitas yang dilakukan pemustaka digital natives terhadap tempat fisik di mana aktivitas yang dilakukannya berpengaruh terhadap proses pemaknaan ruang Perpustakaan Pusat UGM secara lebih khusus. Praktik sosial berarti melakukan apa saja di ruang Perpustakaan Pusat UGM, yang ditunjukkan adanya praktik, aktivitas, dan relasi sosial aktor sehingga ada semacam jaringan interaksi dan komunikasi yang muncul di antara mereka.

Pada saat ruang perpustakaan sudah menjadi bagian dari praktik sosial pemustaka digital natives, maka dapat dikatakan bahwa ruang Perpustakaan Pusat UGM merupakan sebuah produk kultural/budaya. Praktik sosial akan muncul dalam kehidupan sehari-hari di ruang Perpustakaan Pusat UGM. Temuan penelitian ini menunjukkan bahwa secara lived space, pemustaka digital natives menjadi "dominan" karena menggunakan ruang abstrak sebagai alat kekuasaan untuk meraih kendali atas ruangruang di Perpustakaan Pusat UGM. Di samping juga faktanya bahwa pengunjung yang tergolong digital natives memang mendominasi dalam statistiknya. Praktik sosial selalu "mengapropriasi" ruang-ruang fisik di tempat berlangsungnya praktik sosial tersebut. Goonewardena, Kipfer, Milgrom, \& Schmid (2008: 28) menyebutkan bahwa ruang tidak dapat eksis dalam dirinya melainkan selalu diproduksi.

Dari hasil penelitian ada aspek terkait relasi gender yang bisa diungkap. Penelitian ini menunjukkan informan laki-laki suka sekali menonton bola ketika sedang online di ruang Perpustakaan Pusat UGM, sedangkan informan perempuan suka membuka youtube tentang tutorial, misalnya cara memasak dan berhijab modern. Ungkapan "cara memasak" menunjukkan bahwa sekalipun ia berada di lingkungan kampus, di tempat publik (di ruang Perpustakaan Pusat UGM), tetapi ia masih memikirkan juga persoalan yang terkait dengan identitas dirinya sebagai kaum perempuan yang juga bergelut dengan masalah domestik (yang dalam hal ini adalah memasak). Hal ini menunjukkan adanya aspek kebutuhan diri sebagai seorang perempuan yang idealnya mengetahui resep masakan dan cara memasaknya.

Begitu juga aktivitas mengunduh video tutorial berhijab modern ketika berada di ruang Perpustakaan Pusat UGM. Jilbab modis menjadi kebutuhan informan agar bisa tampil lebih modern mengikuti tren anak muda sekarang. Kata "modis" menunjukkan ada sesuatu yang penting bagi informan perempuan karena ada keinginan diri untuk bisa tampil berkerudung dengan model gaya tertentu. Dalam hal ini, berarti ia ada kebutuhan untuk leisure yang mendukung akan penampilan dirinya sebagai seorang muslimah yang berkerudung modis. Keinginan untuk tampil modis menunjukkan adanya kebutuhan untuk tampil lebih percaya diri mengikuti gaya berhijab generasi digital.

Ruang Perpustakaan Pusat UGM oleh pemustaka digital natives juga dipraktikkan sebagai tempat untuk memenuhi kesenangan membaca (reading for pleasure) di waktu luang mereka. Membaca dalam konteks ini, bukan terkait dengan bahan bacaan yang berat seperti buku text silabus perkuliahan, tetapi lebih kepada buku bacaan yang jenisnya termasuk dalam kategori ringan seperti halnya: novel, biografi tokoh, maupun cerita fiksi. Ada juga perbedaan informan laki-laki dan perempuan dalam konteks memilih bahan bacaan. Barker (2013: 195) menyebutkan bahwa gender selalu merupakan masalah bagaimana laki-laki dan perempuan dihadirkan, dan lebih jauh lagi karena gender menjadi konstruk kultural yang terbuka bagi segala perubahan. Hal ini menunjukkan bahwa bahan bacaan terkait juga dengan aspek gender, yang menunjukkan bahwa ada suatu perbedaan perilaku laki-laki dan perempuan yang dikonstruksi secara sosial dan budaya dalam konteks memilih buku atau bahan 
bacaan di ruang Perpustakaan Pusat UGM.

Konsekuensi dari kesenangan membaca tersebut adalah ketika ada perubahan secara fisiologis (misalnya muncul kegairahan) maupun perubahan kognitif (misalnya rasa senang). Hal ini sebagaimana yang ditulis oleh Nell (1988) dari University of South Africa, bahwa kesenangan membaca merupakan sebuah bentuk dari bermain. Artinya aktivitas membaca merupakan sesuatu yang terlepas dari kehidupan sehari-hari, sehingga akan menyerap pelakunya secara total dan membuatnya tidak produktif.

Selama berada di ruang Perpustakaan Pusat UGM diketahui bahwa pemustaka digital natives juga tidak selamanya online. Penuturan informan bahwa saat offline karena memang keinginan diri mereka sendiri. Artinya memang sengaja dikondisikan dan bukan karena sistem jaringan di Perpustakaan Pusat UGM yang lambat atau faktor material teknis lainnya. Jadi bukan karena jaringan yang membuat mereka offline, namun lebih karena pilihannya untuk sekedar ngobrol nongkrong di ruang perpustakaan. Pemustaka digital natives juga sering janjian mengobrol ketemu teman maupun menghabiskan waktu luang di sela-sela rutinitas kuliah di ruang Perpustakaan Pusat UGM.

Temuan menarik lainnya terkait konsumsi ruang secara fisik bahwa dari pengakuan informan yakni sering mengkonsumsi selasar yang menghubungkan antar ruang di Perpustakaan Pusat UGM, sebagai "ruang" untuk memberikan tutorial siswa privatnya. Informan sebagai tutor tidak datang ke rumah siswa tetapi janjian di selasar untuk memberikan tutorial les privatnya. Biasanya siswa pulang sekolah membawa ganti baju trus hunting ke kampus (karena jarak sekolah lebih dekat ke kampus daripada ke rumah). Informan tersebut juga mengkonsumsi ruang Perpustakaan Pusat UGM sebagai ruang producing money secara fisik bagi dirinya. Kondisi ini ruang menjadi sangat cair, tidak birokratis, dan menjadi ruang publik yang mencerdaskan. Hal ini dipengaruhi oleh kondisi material maupun aspek fisik lainnya yang telah dibentuk dan disimbolisasi ke dalam konsep dan tatanan sesuai dengan jenis ruang yang ada di Perpustakaan Pusat UGM.
Berdasarkan konsep leisure yang dikemukakan oleh Veblen, bahwa konsep Veblen digunakan sebagai "kaca mata" untuk menganalisis fakta empiris, namun oleh karena perbedaan konteks maka konsep Veblen menjadi tidak pas dalam konteks pemustaka digital natives. Menurut Veblen, kelas luang memiliki lebih banyak dalam segi ekonomi dan waktu daripada kelas lainnya. Kelas tersebut menggunakan kelebihannya melalui "pemakaian waktu luangnya" untuk hal-hal yang bersifat nonproduktif sesuai keinginannya. Temuan penelitian ini sekaligus juga memberikan kritik pada Veblen.

Konsep Veblen jelas membedakan waktu antara produktif dan nonproduktif (leisure). Dalam konteks penelitian ini, justru dalam "satu ruang perpustakaan" bisa digunakan untuk apa saja oleh pemustaka digital natives. Hal inilah yang dahulu tidak dilihat oleh Veblen karena leisure dalam artian hanya dimiliki oleh orangorang kaya saja. Sungguh berbeda dengan temuan penelitian ini, karena leisure juga bisa terjadi dalam konteks pemustaka digital natives yang tidak memiliki uang sekalipun atau "tidak kaya" namun bisa memanfaatkan ruang perpustakaan untuk menghabiskan waktu luangnya.

\section{E. KESIMPULAN}

Temuan hasil penelitian bahwa pemustaka digital natives memang memiliki motif untuk mengkonsumsi ruang Perpustakaan Pusat UGM. Beberapa temuan menarik dari hasil penelitian di luar konsep "representasi ruang" yang dikonsep sebelumnya oleh perancang ruang. Ruang Perpustakaan Pusat UGM yang bagi konseptor ruang yakni mendukung produksi ide (untuk memenuhi kebutuhan akademik), tetapi yang terjadi dalam lived space sebagai ruang produksi dalam konteks industrial (ekonomi) untuk memenuhi kepentingan di luar kepentingan akademik. Ruang Perpustakaan Pusat UGM dalam praktik sosial pemustaka digital natives dapat menghapuskan sekat antara kerja produktif (belajar) dan nonkerja (leisure). Ruang Perpustakaan Pusat UGM justru bisa digunakan untuk aktivitas kedua-duanya (produktif dan nonproduktif), sehingga 
semuanya menjadi blended dan tidak ada batasan antara kedua ruang tersebut bagi pemustaka digital natives.

Lebih dari 13 jenis ruang di Perpustakaan Pusat UGM yang digunakan oleh informan, baik penggunaan satu fungsi atau berbagai fungsi. Secara representasi ruang, karena ketersediaan sarana dan fasilitas di dalam ruangan yang dikonsepkan oleh konseptor ruang sudah sesuai keinginan informan yang datang ke Perpustakaan Pusat UGM. Ada beberapa dimensi dari aktivitas ketika pemustaka digital natives menjadikan ruang perpustakaan menjadi ruang leisure. Pertama, sebagai ruang untuk mendapatkan kebebasan dari faktor tekanan sosial, lingkungan, dan domestik. Artinya ruang perpustakaan juga sebagai ruang alternatif untuk mencari kebebasan bagi pemustaka digital natives dalam melakukan apapun yang diinginkan. Kedua, ruang untuk mencari hiburan (pleasure) karena menggunakan ruang perpustakaan tidak untuk memproduksi ide (kepentingan perkuliahan), tetapi justru untuk kesenangan yang lain. Ketiga, sebagai ruang katarsis, artinya bentuk pelarian diri (escape) dari berbagai kungkungan, keterbatasan, space yang tidak nyaman, maupun dari berbagai struktur formal yang biasa pemustaka digital natives hadapi di luar ruang perpustakaan.

Ketika berada di ruang-ruang Perpustakaan Pusat UGM, justru pemustaka digital natives bisa bernego dengan aturan-aturan yang ada. Hal ini justru menjadi paradoks karena sebetulnya di perpustakaan banyak sekali aturan. Kenyataannya pemustaka digital natives justru tidak tunduk pada konseptor ruang, sehingga temuan penelitian ini menunjukkan bahwa ruang perpustakaan menjadi ruang yang bisa diterobos oleh pemustaka digital natives untuk melakukan praktik yang berbeda. Ruang perpustakaan tidak lagi menjadi ruang yang menakutkan dengan label birokrasi yang sulit, namun telah bergeser menjadi ruang publik yang dinamis dan cair.

\section{DAFTAR PUSTAKA}

Barker, C. (2013). Cultural studies: Teori \& praktik. Yogyakarta: Kreasi Wacana.

Barner, K. (2011). The library is a growing organism: Ranganathan's fifth law of library science and academic library in the digital era. Library philosophy and practice 2011. Diambil dari http://digitalcommons. unl.edu/cgi/viewcontent.cgi?article $=1579$ \&context=libphilprac

Baudrillard, J. (2009). Masyarakat konsumsi. Terjemahan La societe de consommation. Yogyakarta: Kreasi Wacana.

Blasco, P.G. \& Wardle, H. (2007). How to read ethnography. London: Routledge.

Choy, F. C. \& Goh, S. N. (2016). A framework for planning academic library spaces. Library Management, 37(1/2), 13-28. https://doi.org/10.1108/LM-01-2016-0001

Connaway, L. S. \& Radford, M. L. (2017). Research methods in library and information science (6 ed.). California: Libraries Unlimited.

Fagbola, O., Uzoigwe, C., \& Ajegbomogun, V. O. (2017). Libraries Driving Access to Knowledge in the 21 st Century in Developing Countries : An Overview. Library philosophy and practice 2011. Diambil dari https://digitalcommons. unl.edu/libphilprac/566

Faruk. (2014). Metode penelitian sastra: Sebuah penjelajahan awal. Yogyakarta: Pustaka Pelajar.

Fatmawati, E. (2017a). Functional shift of library: Third space production. In International Conference on South East Asia Studies (ICSEAS) 2nd. Yogyakarta, on September 27-28.

Fatmawati, E. (2017b). Representation of academic library space as interests contestation. In The International Conference of Vocational Studies on Applied Research (ICoVAR). Semarang, on September 13-15. 
Fatmawati, E. (2017c). The interpreting practices of digital native users for library spaces. In The 9th International Graduate Students and Scholars' Conference in Indonesia (IGSSCI). Yogyakarta, on August 9-10.

Fatmawati, E. (2018). Users Information Behavior as a Lifestyle to Build Distinction in New Normal Era. In International Conference On Knowledge and Scholarly Communication. Yogyakarta, May 14-15, 2018.

Goonewardena, K., Kipfer, S., Milgrom, R., \& Schmid, C. (2008). Space, diffrerence, everyday life: Reading henry lefebvre. New York: Routledge.

Gu, X., Zhu, Y., \& Guo, X. (2013). Meeting the digital natives: Understanding the acceptance of technology in classrooms. Educational Technology \& Society, 16(1), 392-402.

Helsper, E. \& Enyon, R. (2009). Digital natives: Where is the evidence? British Educational Research Association, 1-18. Diambil dari http://eprints.lse.ac.uk/27739/

Lefebvre, H. (1991). The Production of Space. Translated by Donald Nicholson-Smith. USA: Blackwell Publishing.

Nell, V. (1988). (1988). The psychology of reading for pleasure: Needs and gratifications. Reading Research Quarterly, 23(1), 6-50. Diambil dari https://msu.edu/ dwong/CEP991/CEP991 Resources/Nell-RdngPleasure.pdf.
Oliveira, S. M. (2018). Trend in academic library space: From book boxes to learning commons. Open Information Science, 2(1), 59-74. Diambil dari https://doi.org/ 10.1515/opis-2018-0005.

Schmid, C. (2008). Henre lefebvre's theory of the production of space: Towards a threedimensional dialectic. In $K$. Goonewardena, S. Kipker, R. Milgrom \& $C$. Schmid (Eds.), Space difference everyday life: Reading henri lefebvre (hal. 27-45). New York: Routledge.

Sequeiros, P. (2013). Reading in public libraries: Space, reading activities, and user profiles. Sociology Review, 9(3), 220-240. Diambil dari http://www.qualitativesociology review.org/ENG/archive_eng.php.

Torkildsen, G. (2007). Leisure and recreation management (5th ed.). New York: Routledge.

Ugwuanyi, CF., Okwor, RN., \& Ezeji, E. (2011). Library space and place: Nature, use and impact on academic library. International Journal of Library and Information Science, 3(5), 92-97.

Veblen, T. (2007). The theory of the leasure class. New York: Menton Book.

Wilson, J. (2013). The devasting conquest of the lived by the conceived: The concept of abstract space in the work of henri lefebvre. Space and Culture, 16(3), 364-380. 